\title{
Business Methods Patent Justifiability Exploration based on Philosophy Perspective of Intellectual Property Rights
}

\author{
Zou Caixia \\ Fudan University Law School Post-doctoral Research Station; Shanghai University of Political \\ Science and Law
}

Email: caier7@163.com

Keywords: Intellectual property rights; Philosophy; Business methods; Patent right;

\begin{abstract}
In traditional sense, business methods only belong to the rule of intellectual activity, and are not listed in the category of patent protection. However, with the development of business, in today's electronic network environment, electronic commerce gets great development. In the late 1990 s, the United States was the first to establish business methods which can be applied for patent protection. Commercial challenged patentability is accepted and there must be a certain theoretical basis.

Science and technology develop accelerate in today's society, and people's speed of innovation are also constantly accelerated. New knowledge innovations emerge endlessly, and people awareness of the protection of intellectual property rights is also constantly strengthened. Such development trend puts forward new requirements for patent law. The main external performance of patent law development is patent right object expanding. But in terms of business method, since its birth, it is ruled out by the patent law, but after the United States took the lead of a business method patent, all countries in the world including Taiwan are quick to follow up the establishment of legal standards of relevant cases, and business methods patent application can be confirmed. Commercial method, as a new type of patents, is based on the development of computer technology and electronic commerce. The patentability of business method helps to safeguard the healthy and orderly development of China's computer and e-commerce industry, and is the decision of intellectual property rights to keep up with the development of The Times, and is the recovery of our country legal system gradually perfecting.
\end{abstract}

\section{Labor theory of intellectual property rights}

Locke's natural law theory is the original source of intellectual property rights theory. In Locke's claims, an important reason of the existence of civil society is to protect people's property rights. His philosophical point of view of intellectual property rights system provides the theoretical basis on philosophy. Knowledge property rights protection is only from modem law. Before it, laws only focus on material property protection. Law gives people financial ownership, and no protection consciousness for knowledge apart from physical things. In modern times, the original natural labor rights had the brand-new understanding, and it was extended to people's intelligence intellectual property rights areas. This is a long historical evolution process. Through the intellectual development of people, the laws of nature are confirmed in law, which provides a theoretical basis for property rights and intellectual property rights legitimacy.

In intellectual property rights of labor theory, knowledge product created is product, such as science, literature, etc. This kind of creative labor has the characteristics of not repeat, high quality. People brought the new things by their own labor for the human society. Whether it is material or spiritual knowledge, people enjoy the ownership of them. But there are certain principles, such as knowledge product must be established on the basis of human society's real needs. People enjoy patent of one product by laws, and it must have certain effect to the society. This is also the legitimacy theory basis of intellectual property rights.

Associating original theoretical activities with business methods, businessmen pay the amount of time and energy in making out commercial method, so the results for business methods are by 
people's labor, even some business method has a certain complexity, which accords with the existing theory of intellectual property, and should enjoy certain rights of their Labor. Business methods are not only business people physical and mental work. In the process of creating, there are materialized labor involving funds and related equipments. If you cannot give the rights protection for the merchants, it will hit the enthusiasm of innovation of commercial method by businessman, which is not conducive to the healthy development of commercial economy.

\section{Intellectual property rights incentive theory}

Look at intellectual property rights legitimacy from the perspective of inspiring intelligence creation, which is the incentive theory we talk about. In existing laws and legal judicial practice, incentive theory has received the confirmation of application. Incentive theory of intellectual property rights is simply, legally established relevant system which provides a legal background for knowledge creation activities, which can stimulate the production of knowledge products, and form a certain society total. Based on more knowledge products, it is sure to produce ideal total social utility, and thus promotes the development of the society. Law incentives for knowledge product creators give the guarantee of the ownership of their own products. Award knowledge products creator property ownership of knowledge products. It can effectively motivate the creation of social knowledge products.

In incentive theory, the state grants intellectual property rights as a creator of encouragement for knowledge, which enables the creator of knowledge products to do more knowledge products to help the country's social economic and cultural development. The ultimate goal of incentive theory is not for personal rewards, but the overall development of society. Through the knowledge of personal property rights incentive, personal knowledge of the product has the ownership in the law, protected by law, the ownership of the creator through law endows the certain material and spiritual rewards, inspired people to create intellectual property rights. Personal knowledge product is eventually to use in social development, and social benefit brought by the intellectual product is far higher than personal benefits. There is a time limit for creators gain benefits from their knowledge products. After this limit, this knowledge product has become a social public product so as to benefit the development of the society. If there is no protection on legal knowledge creator products, the creator cannot get due legal protection, and the creator labor cost can't be returned. Their creative enthusiasm and knowledge production are underpowered, affecting the generation of knowledge product for social development. So, knowledge creator intellectual property rights is the create momentum.

For business methods, businessmen innovate in business way, which is the key to keep the competitiveness in the market. Patent right for developers on business methods is a management method innovation incentive for business operators. If the business operator has no innovation of commercial method, certainly it will be eliminated in the fierce competition in the market. Create new business method is a kind of work, and should be protected by law. Granted business method patent right is the health promoting factor of the sustainable development of country's social business and is in accordance with the requirements of property rights incentive theory.

\section{The balance between business methods patent private interests and public interests}

In Marxist theory, labor is of duality, and the production of goods is not only private labor, but also social labor. The same knowledge as labor commodity product, it has the same properties. However, knowledge production is divided into social labor and personal labor. Social labor refers to the knowledge product cost and products itself have certain social nature. In knowledge production process, labor the creator paid is social, which determines the product's social knowledge. And knowledge product is not consumable products. When using, products boundaries cost is not paid, but in contrast, knowledge products consume a lot in development and production. If with no necessary and legal protection of producers, and try to adjust this case, certainly no one is willing to create knowledge products. In order to promote the development enthusiasm of 
knowledge product, there must be necessary restrictions for the creator, user benefits and costs. This is what intellectual property balance rights need to solve.

Interests balancing principle is the source of intellectual property balance, which is first put forward in the UK to guarantee book author get corresponding remuneration from publishers. Book publishers again through the use of books earn benefits. The connotation of interests balancing principle becomes rich with the development of the society, and has become the basic principle of intellectual property system. In this principle, consider intellectual property owner and social public interests at the same time to achieve the balance of the interests of both. Balance theory of intellectual property rights includes the balance of three aspects, relative balance between the activities of the creator and spread incentives of knowledge products; incentive for creator activities and relative balance of users; social and public interests and private interests. The essence of these three balances is the balance of private interests and public interests. The creator of knowledge products has the ownership of intellectual property rights, which belongs to private interests. Original purpose of the development of commercial method is the developers want to be able to bring certain benefits, promote the development of their business, and the benefits of the commercial method can make up for development and application cost for a patent. Merchants can make profit through their own way, of course, and get expected benefit, but it is an uncertain situation. No matter whether this business method can reach its expectation or not, developers should get exclusive rights in law. Business methods cannot get due protection, then it may prevent the production of good business methods, which is not conducive to the healthy development of social economy, so be on the legal safeguard to develop exclusive rights. But in order to achieve private interest on the balance of public interests in the protection of rights and interests of the developers, also have certain restriction to the rights to ensure the interests of the public. This limitation is mainly time restriction for the validity of business method patent has a regulation of the fixed number of year. In today's established business methods patent, the term of protection of commercial method is no more than 20 years.

Above all, to provide business method patent law protection is the country's protection of business method developer private interests, which conforms to the interests of equilibrium theory, and contributes a lot to promote the development of public interest in the system.

\section{National interests and international interests in business methods patent}

Intellectual property law has the branches of national law and international law, which have different scopes of jurisdiction legal system with different contents. Domestic law is drawn up according to its own internal environment, and the country's economy and the development of science have close relation, so object change of intellectual property rights is first in domestic law to liquidate. Nowadays, regardless of which country, the object scope of intellectual property rights has the trend of widening. With the globalization of economy, science and technology sharing in the global scope, each country increasingly develops intellectual property related legal steps. Some countries form protection of business method patent, in part it is the protection of the interests of the state.

Developing countries and developed countries are of different economic basis, whose science and technology development level also has certain gaps. The balance between interests of developed countries and mutual interests of developing countries is the essence balance of national interests and international interests. The developed countries and developing countries tend to have different ideology, whose behaviors of interest are also different. Because developed countries have more advanced level of economic development, the protection of intellectual property rights is higher than in developing countries. The developed countries, in order to maximize their selfinterest, tend to use their own advantages squeeze the space for development in developing countries. In order to maintain the balance between state interests and international interests, that is the balance of the interests of developing countries and that of developed countries, and promotes the common development of global economy. Developed countries in the process of the pursuit of interests, should leave room for developing countries to grow, considering the legitimate interests of 
competitors. It is the inevitable requirement of gap between developed countries and developing countries, but also the inevitable approach to promote the global harmonious development.

In the 20th century, under the influence of protecting public interests and antitrust theory, the United States in the law does not recognize business methods can obtain patent protection. But in the eighties of the last century, because of the world's rapid development of economic level, and especially European developed countries economic strength enhancement, the United States is affected by the huge international competitiveness, and economic development is slow. Objective historical development show that it pays too much attention to boost the concept of public interest and antitrust, ignore the importance of intellectual property rights protection, which hindered the development of national commercial innovation ability, and is not conducive to national hi-tech research and development. It caused a great loss to national economic interest. For slow economic development America at the end of last century, value the importance of intellectual property rights protection, balance the interests of intellectual property rights owners and the public, establish incentive mechanism of knowledge creation, inspire the creator's study enthusiasm, vigorously support new and high technology research and development are the important ways getting out of the dilemma. So, strong patent protection policy began in the United States, and the new technology computer software development is in the scope of object protection of intellectual property rights.

The history development let the United States to recognize the importance of reasonable protection of intellectual property rights, property rights protection for computer software has been refused originally to now expanding. Diamond v Diehr case was the patent right granted software technology for the first time. It is based on software patent. The United States in 1998 established the feasibility of business method patent. Nowadays, computer technology is in a rapid development momentum, and is particularly important for e-commerce business methods role. Business methods can apply for patents, which can be protected by patent law, and has become an important cause of making inventions for developers.

Through business development process, it can be found that a country's level of economic development and its own technology level in the position in the global decide the country's protection of intellectual property. For relatively science and technology backward country, the protection of intellectual property rights will be weak, while for the country with higher level of science and technology, on the other hand. In business method patent, this phenomenon is more obvious because nowadays there is a close relation between business methods and electronic network, while the global network increases the difficulty of the protection of commercial method, therefore need to develop a strong business method patent protection policy.

\section{Acknowledgement}

1. Post-TRIPS age "Chinese character" intellectual property culture reconstruction----Based on the law philosophy perspectives of intellectual property nature, 2013 Education Ministry Humanities and Social Science Youth Fund Projects. Project financing funds are 80000 Yuan. (Project approval number: 13YJC820120) (Project host)

2. Ecological "natural rights" theory ---- Based on the research of basic theories of ecological method (Project number: CLS (2013) C51-1, Legal issue studies of ecological protection), 2013 general topic of Chinese law society law ministry.

\section{References}

[1] Li Xiaoshu. Business methods patentability research [D]. Fudan University, 2013.

[2] Guan Yonghong. Intellectual property rights are effectiveness research [D]. Wuhan University, 2012.

[3] Ma Zhengyong. Some basic problems in philosophy of intellectual property research [J]. Journal of Ningxia Social Sciences, 2007 01:11-14.

[4] Zhang Chengzhi. Law philosophy basis of intellectual property rights [D]. Anhui University, 
2014.

The author: Fudan University Post-doctoral Research Station; Shanghai University of Political Science and Law

Address: 402, Lane 136, Wen Xiang Road 3088, Songjiang, Shanghai (201620).

Contact: 15900533699 